\title{
キャビテーションの研究の展望*
}

$$
\text { 大場利 三 郎*1 }
$$

\section{Review of Recent Researches on Cavitation}

\author{
Risaburo OBA
}

Key Words : Cavitation, Multiphase Flow, Fluid Machinery, Vortex, Jet

\section{1.はじめに}

19 世紀末にイギリス軍艦に発生した致命的障害(1) が全世界に広く知れ渡り, キャビテーションは国家の 運命に関する重大問題として注目を浴びた，以来，世 界中の国々が競ってキャビテーションの組織的研究に 莫大な費用・人員を投じてきた。しかしながら，キャ ビテーションの多くの種の大部分のものが, 後述する ように, $\mu \mathrm{S}$ オーダの超高速現象 ${ }^{(2)(3)}$ で, 当時の観測法 ではこれらは到底捉え得ないものであったために, 残 念ながら本質的な解明はほとんどなかった。

1936 年になって, 故沼知教授 ${ }^{(4)}$ はキャビテーショ ン初生が試料液の空気含有度によって著しく異なる事 実を示し,キャビテーションはそれまで信じられてき たような単なる状態変化現象ではなく, 蒸気圧, 空気 含有度等の多因子が関与する複雑な物理現象であるこ とを明らかにした。この成果は, 1949 年にアメリカの Crump $^{(5)}$ によって総合的, 系統的に追試され, 確認さ れた。

以来, 多くの物理学者, 機械技術者等によって, キ ヤビテーションの種々の物理的挙動と障害性とが解明 されてきた。ここでまず特記すべきものには, キャビ テーション核理論(6)の急速な発展がある.すなわち, 超高速液流または高圧処理液流等においては, 液体も 固体と同程度の抗張力 ${ }^{(7)}$ を示すので，固体破壊とのア ナロジーが十分成り立つ.そこで, キャビテーション を確率的に生じる液体破壊ととらえ，キャビテーショ ンの挙動特に初生近傍のそれを, 液体中にランダム分

* 原稿受付 1997 年 3 月 28 日.

*1 正員, 埼玉工業大学（369-02 埼玉県大里郡岡部町普済寺 $1690)$.
布し, 液体破壊の端緒となる $\mu \mathrm{m}$ 径の弱点すなわちキ ヤビテーション核（以下単に核という）の特性に支配 されているとする学説の確立である.これによって, キャビテーション初生機構の解明，上流から流入する 核（以下流入核という）による舶用プロペラ性能の著 しい変化 ${ }^{(8)}$ の解明等の数多くの重要課題が解かれた ので, 核はキャビテーション係数 $\sigma=\left(P_{\infty}-P_{v}\right) / q_{\infty}\left(q_{\infty}\right.$ $=\rho U_{\infty}^{2} / 2, P_{\infty}, U_{\infty}$ は代表点の静圧および流速， $P_{v}$ は 蒸気圧， $\rho$ は流体密度）以外の支配因子であるという 認識が定着したそそして，キャビテーション試験の不 可欠な条件として核の実測の必要性が広く認識され た(9).また，核の成長環境，すなわち，低圧領域と核 を安定的に保持するコヒーレント流れ構造，例えば， 強せん断層内の渦(10), 突出噴流渦(11)，はく離泡(12) な どの役割も次第に明らかになった。

当時は，しかしながら，超高速観測法が未発達であ ったことから，キャビテーションの流体力学的基本要 素であるキャビテーション気泡（以下気泡という）の 認識はかなり雑のそしりは免れず, 変化が比較的遅く, 観測が容易な球状気泡のみが存在するとする，いわゆ る一元論がまかり通っていたようである。ホログラフ イ法, ns オーダの低発熱・高輝度せん光ランプと高速 ビデオの組合せ法, CCD カラとレーザライトシー 卜法の開発, 画像処理法の急速な発達等により, キャ ビテーションを構成する多種の気泡の大部分が明りょ うに観測できるようになった 1970 年頃から，ようや く各種の気泡の相次ぐ発見があって, 50 種以上のもの から非常に複雑に多元的に構成されているキャビテー ションの害体 ${ }^{(2)(13)}$ がようやく認識されるようになっ た，言うまでもなく，異なる種とは，独自の様相を呈 するのみならず, 成因, 障害性（キャビテーション壊 
食（以下壊食という）の観点からは，多くの種は幸い にして低壊食性で，著しく高壊食性のものはごくまれ である(14)), 初生法則が異なるものをいう. Beaufrére $^{(15)}$ は異なるタイプの気泡について確かに 述べているが, この意味において, 著者らの種の議論 には至っていない.

典型的確率事象である(2)(16) キャビテーションの一 義的規定には，言うまでもなく，平均的気泡発生領域 を主として規定するキャビテーション係数 $\sigma$ のみに よる従来法は明らかに不十分で, 少なくとも $2 \sim 3$ 個 の支配因子の規定は不可欠な条件である. そして，こ の条件は, 上記のように, $\sigma$ の他に核, 気泡の種, コヒ ーレントな流れ構造が支配因子**1 として認知される ようになった昨今ようやく満足されたわけである.こ の意味においては, キャビテーション学の基盤がよう やく今日確立したとも言えよう．本文では，最近急速 に進展しつつあるこの新キャビテーション学について 展望する。

\section{2. 発 生 機 構}

以下の議論の都合上, キャビテーションの発達段階 をまず規定しておこう．気泡の様相と内圧 $P_{c}$ の係数 $\sigma_{c}=\left(P_{\infty}-P_{c}\right) / q_{\infty}$ を示した図 1 に明らかなように, 流 速 $U_{\infty}$ が増し, $\sigma$ が低下すると, まず少数の気泡が確 率的に初生（図中には, その平均の $\sigma_{i}$ を示す）し，次 いで，時間・空間的に確率的に発生する多数の各種気 泡により多元的に構成されているサブキャビテーショ ン（以下 Sub.Cという）に発達し, Sub.Cとスーパ ーキャビテーション（以下 SCという）とが極めて不 安定的に交番している遷移領域を経て, 境界層はく離

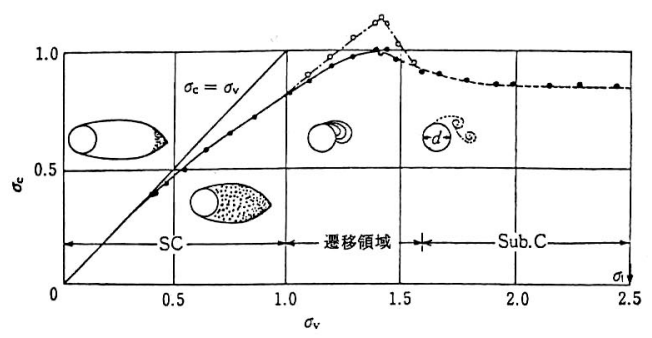

Fig. 1 Developing range of cavitation

**1 周知の $\pi$ 定理によって, 任意に因子を $2 \sim 3$ 個選べば, 他の因 子はこれらの因子の関数関係があることになる.核，気泡の 種, コヒーレントな流れ構造の間にも，例えば渦キャビテー ションと渦流れのように, 場合に応じて相互関係があるが, 残念ながら，いまだこの相互関係が十分解明されていない現 状では，安全のためにこれらを併記した研究が行われている。
領域あるいは後流内に安定的 SC 空洞が発達している $\mathrm{SC}$ 領域へと移行している. そして, 流体機械・機器

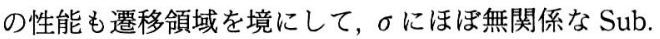
$\mathrm{C}$ 性能から高 $\sigma$ 依存性の SC 性能へと移行してい $ろ^{(17)(18)}$.

$2 \cdot 1$ 遷移領域の上限（性能变化点）流体機械の 性能劣化が始まる $\sigma_{B}$ ブレーキすなわち Sub. Cより $\mathrm{SC}$ 一遷移する領域の上限は, 機械使用限界, また, 超高速 SC 機械の適用限界として技術者達から重要視 されている. 一方, 壊食速度すなわち壊食率が通常の キャビテーションの, それの 100 倍以上に達する致命 的な激しい壊食 (後述) ${ }^{(18)(20)}$ も正にこの領域で発生 する. なぜなら, 非常に不安定的に成長・崩壊を絽返 すこの領域特有の大渦流, または, 突出噴流 ${ }^{(11)}$ がそこ にあり,さらに, 気泡量がかなり多いことから, 音速 が非常に低下し, 衝撃波が容易に発生するからであ る。そこで，この上限点について少々述べう。

Florschuetz ら (21) によれば, 気泡成長の初期には力 学的要因が支配的に効くが, 遷移領域のように十分気 泡が発達した段階では熱的要因が支配的になる。さ て, 性能劣化は主として気泡によるはく離誘発に起因 するから, 上限点は, はく離点近傍の気泡量にかかわ る熱的因子すなわち蒸発量によって決まる。したがっ て, 液体を $\Delta P$ だけ降圧し， $\Delta T$ だけ温度を低下させ た場合に単位質量当たりの蒸発量を示すヤコブ数 $J_{a}$ が上限点の支配パラメータといえる. 周知のように, Stepanoff(22) は, この $J_{a}$ を $B$ ファクタと称し, これ を用いて高温水抢よび水以外の液体（液体水素, $\mathrm{LPG}$, 液体 $\mathrm{Na}$ 等）を作動流体とするポンプの $3 \%$ 揚 程低下点 (一種の $\sigma_{B}$ ) を定量的に評価している. そ の後, この重要課題の研究には, なぜか数編の論 文(23) (27) が散見されるだけであるから, 今後の発展を 切望する。

$2 \cdot 2$ Sub. C 気泡の初生 初生は, 時間・空間的 に確率分布している核 ${ }^{(3)(9)}$ と種々の低圧・核の環境 (コヒーレント流れ構造など）によって支配されてい

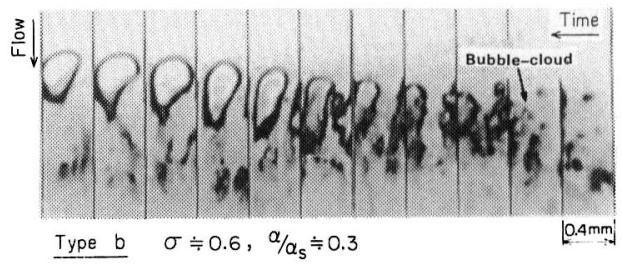

Fig. 2 Highspeed microscopic photographs on cavitation nuclei of bubble- and cloud-type 
るから, 各種の気泡は多元的・確率的に発生する ${ }^{(28)}$. 核は, 液体の典型的な引張破壊を結果する $1 \mathrm{~nm} \sim 1$ $\mu \mathrm{m}$ 径のホール核と, 引張強さがほとんどない $1 \sim 100$ $\mu \mathrm{m}$ 径のガス泡または蒸気泡を結果する気泡核という 特徵的な二つから成っている(29)(図 2 参照) から，か なり強い衝撃波の極低圧などにより，液体の一部分に 微小破壊クラックの大群が発生し, 気泡雲状を呈する ものから, 気泡核が臨界径以上に成長すると不安定的 に急成長し, 可視気泡になるという特徴的なものとに 大別され得よう。まず, 後者については, 気泡核の半 径 $R$ は微小だから, 球状核と仮定し, 核が気泡方程式 に従うものとして, 核が臨界半径を超えて不安定的に 急成長・急崩壊し始める点すなわち初生点・消滅点を 算定した研究(29)(30)によれば，これらの点に効く因子 には, キャビテーション係数 $\sigma$, レイノルズ数 $R_{e}$, ガ ス含有度, 渦・乱れなどによる減圧係数, ウエーバ数, ヤコブ数 $J_{a}$, 寸法係数, 無次元振動数, マッ八数 $M$ 等があり, 明らかに, 初生等は多因子依存性現象であ

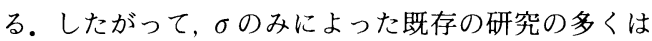
明らかに誤りで, ガス含有度を考慮した沼知のガス泡 の研究(4) は正統的研究の第一歩であったと言えよう.

言うまでもなく, 炭酸水, 油, 含繊維水等に発生す るガス泡は, ガスの分圧すなわちガス含有度に支配さ れて非常に緩慢に成長するので，低壊食性であるのに 対して, 流動泡は, 上流から流入する大径核（流入核） または境界層内で滞留しつつ増殖された核に主として 支配されて，急激に成長・崩壊する。また，流入核に 鈍感な渦泡, 細管列状泡またはバンド気泡は, 十分な 低圧とガス過飽和状態に長時間さらされて増殖された ガス性の核から発生するから，一般に低壊食性である が, 例外的に渦泡の中に極めて高壊食性で激しい壊食 を結果するものがある．この点は，後述する激しい壊 食の機構にかかわる重大問題なので, 少々詳しく考究 してみよう。

渦は周囲の気泡群を引き寄せて, 渦コア内の低圧部 に集積する機能を持っている(10)ので, 流入核が多い 場合, 渦内には非常に多くの気泡が集積されるから, 渦泡内の音速は非常に低下し, 渦流の急変に伴う内在 大気泡の崩壊によってしばしば非常に激しい衝撃波が 発生し(31) (33), 激しい壊食を結果する。このような渦 流の急変化については，激しい壊食のみならず，機械 の致命的激振とのかかわりもあって, 最近注目を浴び ている、いったんキャビティが発生すると, その周囲 圧はますます低下するから，キャビティは局所的に不 安定的に急成長し, 非常に強い渦流の急変を伴った突 出キャビティ噴流を結果する(11)(34) (36). 予想されるよ
うに, 噴流の前面が急速に加速されているこの種の噴 流では跳ね返り噴流がより顕著に現れる ${ }^{(35)}$.

次に, ホール核より生じる気泡雲について述べる. Fisher $^{(37)}$ や Finch ${ }^{(38)}$ が速度過程論によって液体破壊 の引張強さを定量化した研究から明らかなように, 液 体の分子運動によって絶えず非常に大量にホール核が 生成されているから, 所与の引張応力状態では, 大量 の微細気泡群として初生することは予想され得よう。 そして, この予想は, はく離泡内の核の顕微鏡超高速 写真観測（図 2)(12)によって裏づけられた。 また, ガ スをほとんど内在しない極微小径核は極めて不安 定(29)であるから, 現在の測定にかからないほど高速 に成長しているはずである（この発生機構の解明のた めに, 顕微鏡超高速写真法のさらなる発達を期待す る).

このように, 大量の微細気泡群を含む流れを近似的 に均質二相流と見なせる場合があろう。このような流 れの局所流速が音速を超える臨界キャビテーション係

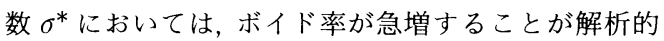

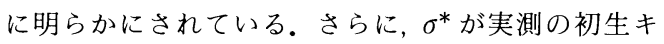
ヤビテーション係数 $\sigma_{i}$ にかなり合う場合があるこ と(39)も知られている. したがって, ホール核からの 気泡雲も 2 種以上のものから多元的に構成されている 可能性がある.

\section{3. キャビテーションの制御}

$3 \cdot 1$ 性能劣化の防止 キャビテーションが発生 すると流体機械の性能は劣化すると昔から言われてき たが，これは正しくない（正確な認知法がなかったの で誤認していたのであろう)。例えば，翼形を例にと れば，未発生状態より $\sigma$ を次第に下げていくと，まず 初生し, そして, かなり発生しても Sub. C 領域では性 能はほとんど変化しない.さらに $\sigma$ が低下し, はく離 した SC 流れに移行して, 初めて性能が劣化する(40). 特に, 炭酸水, 液体水素, 油, 含繊維水などのように多 量のガスを含む液体（ガスの分圧 $P_{g}$ は十分高い）の 流れでは, 実質的なキャビテーション係数 $\sigma_{a}=\left(P_{\infty}\right.$ $\left.-P_{g}\right) / q_{\infty}$ は 0 近傍まで低下し, 著しく性能が劣化する 場合が多い(41).

このような性能劣化は, 翼形を十分反らせ, 腹面で 負荷を支える SC 翼形(17) を採用すれば, 腹面圧には限 界がないので， $\sigma \rightarrow 0$ の極端な場合でもかなりの負荷 を支え, かなりの性能が期待できる. また, 低速, 高 速のいずれでも高性能を呈するような背面, 腹面を持 つ複合 SC 翼形(42) の形状は十分薄く, 弓のように反っ ており, 遠心ポンプの羽根に酷似している.そこで, 


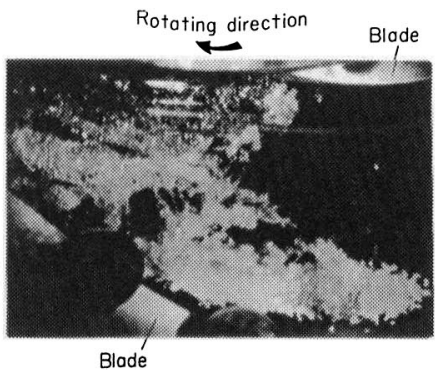

Fig. 3 Singular vortex cavitation resulted by an unstably rapidly developed jet and the resulted severe erosion

特に大量の空気を含む含瀻維水流用ポンプにおいて

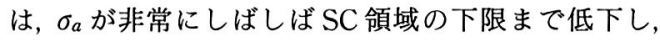
著しいポンプ性能低下と水繊維混合物の流動性低下と により致命的繊維閉塞が生じるので，これを防止する ために, 主板上の孔より真空ポンプで空気を吸い出し， $\sigma_{a}$ を Sub.C 領域まで上げる手法が成功裡に行われて いる(41)．著者は，多量にガスを含む液体用のポンプの キャビテーション性能の向上，あるいは，超高速 SC 機械の部分負荷特性（通常の固体羽根を用いた機械で は劣悪となることは避けられない(17) ので, 可動フラ ップ, ジェットフラップなどのかなり複雑な機構の採 用が提案されている）の向上には，この $\sigma_{a}$ 制御法が 極めて有効と考えている.

また, $\mathrm{SC}$ 領域でのみ発生するキャビテーション・ フラッタ(43) は，もちろんフラッタ限界曲線を考慮し て, 羽根系を設計することによっても防止できるが, 上記の $\sigma_{a}$ 制御法により効果的に防止できるはずであ る。さらに，遷移領域で起きる激しい壊食および激振 も据付条件を変えて $\sigma$ を変えるか，あるいは，上記の 吸気または通気による $\sigma_{a}$ 制御法で防止できよう。

\section{$3 \cdot 2$ 激しい壊食の制御 機械の寿命に直結する} 激しい壊食は，かなり大径の核を安定的に保持・供給 する機構（例えば上流キャビテータ(19)），十分に大径 の気泡への急速成長を促す極低圧, 高圧下での十分大 径気泡の崩壊の伴う十分強い衝撃波の発生とによって 支配されているから，一般には機械の種類，作動条件， 材質はもとより, 作動流体の物性（特に大径核の状態 は時々刻々大いに変わるので, 現状ではそれを十分把 握していない), 急速に変動する流れ（特に流体エネ ルギーを局所的に極端に集中し，かつ，大径核を安定 的に保持する極めて強い渦), 強力超音波音場, 突出噴 流などのコヒーレント流れ構造に支配されている.

既に, 最近の拙文「壊食はなぜ起こるか」(43)にお いて,この種の壊食の制御法について詳述したので,
ここでは紙数の関係で再録は避ける，上述したよう に, 激しい壊食は流体機械にとっては致命的なもので あるが, 大径核, したがって, 壊食の状態が時々刻々 大いに変化するためか, 実機に発生した激しい壊食の 実状（比較的短時間に激しい壊食を受けた事実を示す 損傷例は多数報告されたが，壊食の機構，経過，制御 法についてはほとんど知られていない）があまりにも 知られていない現状にかんがみ，この実状の精密調查， あるいは，大径核およびキャビテーションの様相（高 壊食性キャビテーションの種）を十分把握した壊食試 験の重要性がにわかに叫ばれている。幸いにして，我 が国では, ターボ機械協会および主要ポンプメーカー 各社よりの援助の下に, この種の組織的, 系統的研究 が既に行われ，このように壊食は羽根車内の突出噴流 に起因する高壊食性渦キャビテーションによるものて ある（図 3 参照）こと，大径核を供給する上流キャビ テータを取り除くことによって激しい壤食が回避でき ることなどを明らかにし，かなりの成果を挙げた(44). ほとんど時を同じくして, フランス, カナダ, スイス の研究者達が水車に発生する激しい壊食の総合的研究 を行っている(45).

\section{4. おわりに}

以上, キャビテーションの研究を展望した. 皆様に いささかでもお役に立てば幸いである.

\section{文献}

(1) Thornycroft, J. and Barnaby, S. W., Proc. Inst. Civ. Engrs., 122 (1895), 51.

(2) Knapp, R. T., ほか 2 名, Cavitation, (1970), 104, McGraw Hill.

(3) Oba, R., ほか 4 名, Trans. ASME, Ser. I, 108 (1986) 438-443.

(4) Numachi, F., Ing. Arch., 7 (1936), 396-406

(5) Crump, S.F., David Taylor Model Basin Rep., 575 (1949)

(6) Kernard, E. H., Phys. Rev., 63 (1943), 172-181.

(7) Harvey, E. N., ほか 2 名, J. Appl. Phys., 18 (1947), 162172.

(8) Albrecht, K., ほか 1 名, Trans. ASME, Ser. I，97 (1975), 523-532.

(9) Morgan, W. B., Proc. 13th ITTC, Berlin/Hamburg, (1972), 657-675

(10) Daily, J. W. and Johnson, V. E. Jr., Trans. ASME, 78 (1956), 1695-1706.

（11）祖山 均，ほか3 名, 夕ーボ機械, 21 (1993), 215-219.

(12) Ito, Y., ほか 1 名, Trans. ASME, Ser. I, 107 (1985), 121-126.

(13) Oba, R., ほか 2 名, Trans. ASME, Ser. I, 100 (1978), 493-499.

(14) Knapp, R. T., Trans. ASME, 77 (1955), 1045-1054

(15) Beaufrére, J., Houille Blanche, 4 (1962), 521-536.

（16）大場利三郎, 機誌, 82 (1979), 666-671. 
（17）斎藤清一, スーパーキャビテーション, (1972), 26, 菜根出 版.

(18) Oba, R., ほか 2 名, Trans. ASME, Ser. I, 102 (1980), 433-440.

(19) Soyama, H., ほか 5 名, Proc. 15th IAHR Symp. Cavi.\& Fluid Mach., Belgrade, (1990), H4

（20）祖山 均, ほか 4 名, 夕ーボ機械, 18 (1990), 699-707.

(21) Florschuetz, L. W., ほか 1 名, Trans. ASME, Ser. C, 87 (1965), 209-220.

(22) Stepanoff, A. J., Trans. ASME, Ser. A, 86 (1964), 195202.

（23）佐藤恵一，ほか 5 名，東北大学速研報告, 46（1981），115128.

(24) Billet, M. L., ほか 2 名, Trans. ASME, Ser. I, 103 (1981), 534-542.

(25) Fruman, D. H., ほか 2 名, ASME Cavi.\& Multiphase Flow Forum, FED 109 (1991), 93-96.

(26) Holl, J. W., ほか 2 名, Trans. ASME, Ser. I, 97 (1975), 507-514.

(27) Kato, H., Int. Symp. Cavi. Incept., ASME FED, (1984), 127-136.

（28）大場利三郎, ほか 1 名, 機論, 45-389, B (1979), 72-80.

（29）大場利三郎, ターボ機械, 10 (1982), 221-228.

(30) Arndt, R. E. A., Symp. High Powered Propul. of Ships, NSMB, (1974), Pap. 21.

（31）祖山 均, ほか 3 名, 機論, 60-572, B (1994), 1133-1138.
(32) Sato, K., ほか 1 名, Proc. 1996 ASME Fluid Eng. Div. Conf., FED 236 (1996), 485-490.

(33) Oba, R., Proc. 2nd Sympo. Cavi., Tokyo, (1994), 1-8.

(34) Avellan, F., ほか 1 名, ASME Int. Symp. Cavi.\& Ero sion in Fluid Syst, FED-88 (1989), 119-125.

(35) de Lange, D. F., ほか 2 名, 2nd Int. Symp., (1994)、4550.

(36) Kawanami, Y., ほか2名, Proc. 1996 ASME Fluid Eng. Div. Conf., FED 236 (1996), 329-336.

(37) Fisher, J. C., J. Appl. Phys., 19 (1948), 1062-1067.

(38) Finch, R. D., Phys. Fluids, 12 (1969), 1775-1778

(39) Kamiyama, S., ほか1名, Proc. 10th IAHR Symp., Tokyo, (1980), 53-62.

（40）奈良坂力, ほか 5 名, 機論, 55-519, B (1989), 3397-3402.

（41）伊藤幸雄, ほか 4 名, 夕一ボ機械, 23 (1995), 327-331.

(42) Lang, T. G., AIAA Paper, 69-396 (1969).

（43）大場利三郎, ターボ機械, 24 (1996)，262-266.

(44） 夕ーボ機械協会ポンプのキャビテーション損傷研究分科 会研究成果報告（第 1 期, 1990). (第 2 期, 1994)，(第 3 期, 1997).この内容の多くは国際会議等で発表.

(45) Bourdon, P., ほか 6 名, Proc. 18th IAHR Symp. Hydra. Mach. \& Cavi., Valencia, (1996), 534-543.

(46) Dorey, J. M., ほか 5 名, Proc. 18th IAHR Symp. Hydra. Mach. \& Cavi., Valencia, (1996), 564-573.

(47) Dupont, P. H., ほか 10 名, Proc. 18th IAHR Symp. Hydra. Mach. \& Cavi., Valencia, (1996), 574-583. 